\title{
Tumor Necrosis Factor Alpha 308 Genepolymorphism and Serum Osteoprotogerin Inarteriovenous Fistula Dysfunction Inhemodialysis Patients
}

\author{
Sherif Aziz Zaki ${ }^{1}$, Iman Ezzat Elgohary ${ }^{2}$, Doaa Ibrahim Hashad ${ }^{3}$, Mamdouh Ahmed Zidan ${ }^{4}$, \\ Walaa Saad Ali Hefnee ${ }^{5}$ \\ ${ }^{1}$ Department of Internal Medicine, Faculty of Medicine, Alexandria University, Egypt \\ ${ }^{3}$ Department of Clinical Pathology, Faculty of Medicine, Alexandria University, Egypt \\ ${ }^{4}$ Department of Radiodiagnosis, Faculty of Medicine, Alexandria University, Egypt
}

\begin{abstract}
Introduction: The preservation of patent, well-functioning dialysis fistulas is one of the most difficult clinical problems in the long-term treatment of patients undergoing dialysis. Arteriovenous fistula (AVF) dysfunction remains a major contributor to the morbidity and mortality of hemodialysis patients. The goal is to identify a dysfunctional AVF early enough to intervene in a timely manner to either assist with the maturation process or to prevent thrombosis. Over the past years, numerous clinical studies have consistently reported higher serum levels of OPG in association with cardiovascular outcome including coronary artery disease (CAD), vascular calcification, advanced atherosclerosis. Genes encoding for TNF-alpha are potential genetic risk factors for atherosclerosis and have functional variants that regulate their expressions. Polymorphisms at the position -308 in the promoter region of the TNF-alpha gene have been implicated as risk factors for atherosclerosis.Factor $V$ Leiden mutation (G1691A) has been recognized to be the most prevalent genetic risk factor for venous thrombosis. Aim of the work: The aim of the present work is to investigate TNF-alpha 308 gene polymorphism,factor V Leiden mutation (G1691A), and serum osteoprotogerin level in patients on maintenance hemodialysis suffering from vascular access dysfunction. Subjects \& methods: The study included 60 end stage renal disease patients from Alexandria University Hospitals on maintenance hemodialysis who were divided into 2 groups; 40 patients with AVF dysfunction, 20 patients with normal functioning AVF , 20 age and sex matched healthy subjects of matched age \& sex were used as a control group. Investigations include serum level of Osteoprotogerin by ELISA technique, Serum TNF-alpha- 308G>A-polymorphism by real time PCR and factor VLeiden gene mutation was assessed using 5' Nuclease assay as well as Doppler ultrasound for vascular access. Results: As regard TNF alpha 308 genepolymorphism there was statistically significant difference in the group with dysfunctioning AVF compared to the other two groups while factor $V$ laden gene mutation showed statistical significant difference in group with AVF dysfunction \&control group while no significant difference between them and those with functioning AVF. OPG was higher in group with AVF dysfunction compared to those with functioning $A V F$ \& control group while there was no significant difference betweenfunctioning AVF \&control group. Conclusion: both OPG and the genotype distribution of TNF- $\alpha-308 G>A$ can be used as potential markers on HD patients to detect AVF dysfunction while, the role Factor $V$ Leiden gene mutations may need further research and investigations.
\end{abstract}

Keywords: AVF dysfunction, TNF-alpha- 308G>A-polymorphism;Osteoprotegrin؛ factor V laden gene mutation

\section{Introduction}

A successful functioning vascular access is the "lifeline" for a hemodialysis patient. ${ }^{[1]}$ Arteriovenous fistulae (AVF) are the preferred vascular access for hemodialysis patients, because once mature and functional, they require fewer interventions to maintain patency and develop fewer infections compared toarteriovenous grafts $(\mathrm{AVGs})^{[2,3]}$. However, AVFs have higher rates of non-maturation and longer maturationtimes compared to AVGs. ${ }^{[4,5]}$

The failure of a newly created AVF to mature and development of stenosis in an established AVF are two common clinical problems. ${ }^{[6]}$

In AVF and AVG, the most common cause of this vascular access dysfunction is venous stenosis as a result of neointimal hyperplasia within the peri-anastomotic region of AVF or at the graft-vein anastomosis ${ }^{[7]}$. There have been few effective treatments to-date for venous neointimal hyperplasia in part because of the poor understanding of the pathogenesis of venous neointimal hyperplasia. ${ }^{[8]}$ The goal of most researches is to identify a dysfunctional AVF early enough to intervene in a timely manner to either assist with the maturation process or to prevent thrombosis. The currently available tools include clinical evaluation, physical examination of the AVF, and surveillance tests but they are not enough so; there is a need to identify those patients at risk of development of AVF dysfunction.

Vascular inflammation plays a key role in the development of atherosclerosis in hemodialysis patients (HD). This role of vascular inflammation may be involved in the thrombosis process of AVF in this population. Tumor necrosis factor alpha (TNF- $\alpha$ ) is a cytokine found in human atheromatous lesions and modulates inflammatory cellular response in atherosclerotic process. Genes encoding for TNF- $\alpha$ are potential genetic risk factors for atherosclerosis and have functional variants that regulate their expressions. Polymorphisms at the position -308 in the promoter region the TNF-a gene are associated with higher rate of transcription of gene and have been implicated as risk factors for atherosclerosis. ${ }^{[9,10]}$ 


\section{International Journal of Science and Research (IJSR) \\ ISSN (Online): 2319-7064}

Index Copernicus Value (2013): 6.14 | Impact Factor (2015): 6.391

Osteoprotogerin (OPG), a member of the tumor necrosis factor receptor superfamily, is a soluble decoy receptor for the osteoclast differentiation factor receptor-activator of nuclear factor $\kappa \mathrm{B}$ ligand (RANKL) that inhibits interaction between RANKL and its membrane-bound receptor RANK. The RANKL/OPG/RANK axis has been shown to regulate bone remodeling ${ }^{[11]}$ and was more recently found to be linked to the development of atherosclerosis andplaque destabilization.[12] In observational studies, elevated circulating OPG levels have been associated with prevalence and severity of coronary artery disease, cerebrovascular disease, and peripheral vascular disease. Circulating OPG levels are increased in patients with acute coronary syndrome, and enhanced expression has been found within symptomatic carotid plaques. ${ }^{[13-15]}$

Several inherited factors that predispose to thrombosis have been identified. ${ }^{[16]}$ Factor V Leiden mutation (G1691A) has been recognized to be the most prevalent genetic risk factor for venous thrombosis. Factor $\mathrm{V}$ play a major role in homeostasis by converting prothrombin to thrombin. ${ }^{[17]}$

So, this study was conducted with the aim to investigate TNFa308 gene polymorphism, factor VLeiden mutation (G1691A), and serum osteoprotogerin level in patients on maintenance hemodialysis suffering from vascular access dysfunction.

\section{Patients \& Methods}

The study included 60 end stage renal disease patients on maintenance hemodialysis who were recruited from dialysis units of Alexandria University hospitals. The patients were divided into two groups 40 patients with AVF dysfunction\& 20 patients with normal functioning AVF. 20 age and sex matched healthy subjects were included as a control group

Patients with history of diabetes mellitus,coronary artery diseases, bone disease and autoimmune diseases were excluded from the study. Also, hypotensive, obese, and those taking anti-inflammatory drugs were excluded.

The study was conducted in accordance with the ethical guidelines of the 1975 Declaration of Helsinki and an informed consent was obtained from each patient and control in the study.

Each subject had medical history taken as well as, full clinical examination stressing on vascular access (The flow, presence of thrill, aneurism, singes of inflammation and obstruction).

Fasting blood samples were collected for serum cholesterol, serum triglyceride, low density lipoprotein (LDL), high density lipoprotein (HDL), complete blood count, renal function tests (blood urea, serum creatinine), Serum calcium level, Serum phosphate level, Intact parathyroid hormone level (iPTH), high sensitive CRP (hs- CRP) using standard laboratory protocols.

\section{Osteoprotogerin $^{[18]}$}

Detection of serum level ofOsteoprotogerin was done using sandwich enzyme linked immunosorbent assay (ELISA) technique (DRG International, Inc. USA)
TNF-alpha- 308G $>A$ polymorphism and Factor V Leiden mutation polymorphism ${ }^{[19,20]}$

Genomic DNA was extracted from whole blood by standard methods using the Pure Link® DNA kit (life technologies, CA, USA).Checking DNA quality and quantity was performed using Nano Drop (Thermo Scientific, USA). All samples were stored at $-20^{\circ} \mathrm{C}$ till further analysis.

Samples were genotyped for TNF-alpha- 308G>Apolymorphism and Factor $\mathrm{V}$ Leiden mutationusing a TaqMan $5^{\prime}$-allele discrimination Assay-By-Design method (Applied Biosystems, Foster City, CA). The genotyping was performed on Rotor-Gene Q (Qiagen,Hilden, Germany).

TaqMan allelic discrimination was performed in $25 \mu \mathrm{L}$ reaction volume containing the Universal $2 \mathrm{x}$ TaqMan ${ }^{\circledR}$ Master Mix (Applied Biosystems, Foster City, CA, USA), and the 20X Assay ready-made stock for both genes. Thermal cycling profile included an initial step at $95^{\circ} \mathrm{C}$ for 10 minfollowed by 40 cyclesof $95^{\circ} \mathrm{C}$ for $15 \mathrm{sec}$ (denaturation step) and $60{ }^{\circ} \mathrm{C}$ for 1 min (annealing/extension).

\section{Radiological study}

Doppler ultrasound was done for assessment of AVF function and presence of thrombosis, calcification, obstruction or presences of steal phenomena using Siemens prima ultrasound system.

\section{Statistical analysis of the data: ${ }^{[21]}$}

All calculations were performed on a personal computer with IBM SPSS software package (version 20.0) for Windows. ${ }^{[22]}$ Qualitative data were presented as numbers (n) and percentages (\%) was compared using Chi square or Fisher Exact test. Quantitative data were presented as means and standard deviation (SD). Comparison between the means of quantitative variables was performed using the one-way ANOVA (F-test). While abnormally quantitative data expressed in Median (Min. - Max) and was compared using Mann Whitney or Kruskal Wallis test.

The correlations between different variables were evaluated by Pearson or Spearman correlation coefficients according to the distribution of variables (continuous or discontinuous quantitative variables respectively). $\mathrm{P}$ value $\leq 0.05$ was accepted as statistically significant.

\section{Results}

Clinical and biochemical characteristics of the study subjects are presented in table (1)

Serum calcium, serum phosphorus, serum intact parathormone level, Total cholesterol, triglyceride, LDL, HDL, have a significant difference all through the three groups $(\mathrm{p}<0.001)$.

OPG level was higher in the group with AVF dysfunction compared to both the group with functioning fistula and controlgroup $(\mathrm{p}=$ and respectively), while there was no significant difference between functioning AVF \&control group. $(\mathrm{p}<0.001)$.table(2). 


\section{International Journal of Science and Research (IJSR) \\ ISSN (Online): 2319-7064}

Index Copernicus Value (2013): 6.14 | Impact Factor (2015): 6.391

Also we found hsCRP positively correlated to serum OPG level $(\mathrm{p}=0.004)$.

Regarding TNF alpha 308 gene polymorphism,in patients with AVF dysfunction 27 patients were heterozygous which was significantly higher than group with functioning AVF where only 5 patients were heterozygous while in control group there was 8 subjects heterozygous, and no significant difference between patients with functioning AVF \&control group. $(\mathrm{p}=0.005) \cdot \operatorname{table}(2)$

Factor V laden gene mutation 16 patients were wild in functioning AVF\&29 patients with dysfunction and 13 in control group while heterozygous there was 1in functioning AVF ,9 patients with dysfunction \&zero in control group .as regard gene mutation there was 3patients mutant in functioning AVF ,2 patients in dysfunctioning fistula and 7 in control group which means that there was no significant difference between dysfunction AVF\& functioning one. $(\mathrm{p}=0.104)$ while there was significant difference between group with dysfunction \&control $\operatorname{group}(\mathrm{p}=0.002) \cdot \operatorname{table}(2)$

So in this work we found there is significant difference between the group with AVF dysfunction and those with normal AVF as regard TNF alpha 308 gene polymorphism $(\mathrm{p}=0.002)$, the same for OPG level was higher in group with dysfunction fistula compared to the normal functioning AVF $(\mathrm{p}<0.001)$ while factor $\mathrm{V}$ laden gene mutation there was no difference between thetwo groups as $(\mathrm{p}=0.105)$.table $(3)$.

Doppler ultrasound for AVF showed 9cases with calcification and 11 patients thrombosis \&calcification with average flow volume.(mean \pm SD968.60 $\pm 115.07 \mathrm{ml} / \mathrm{min}$ )

\section{Discussion}

Inflammation proposed to play an important role in the initiation and progression of atherosclerosis in ESRD, but may also play a significant role in vascular access stenosis and thrombosis. ${ }^{[23,24]}$

In the present study it was found that hsCRPwas significantly higher in the group with AVF dysfunction compared to those with normal functioning AVF this supports the role of inflammation in fistula dysfunction.

Zadeh et al, ${ }^{[25]}$ studied the role of inflammation in failure of AVF and evaluate the hematologic and inflammatory biomarkers in early AVF failure. Theyincluded 110 ESRD patients, whom were undergone AVF creation, divided in two groups and they found CRP was positive in 34 patients $(61.8 \%)$ with unsuccessful fistula function, while only 4 (7.3\%) of those with successful AVF had positive CRP and the rest had negative CRP.

Tumor necrosis factor- $\alpha$ (TNF- $\alpha)$ is a cytokine that initiates the inflammatory cascade and may contribute to inflammation in renal failure. Promoter polymorphisms of cytokine genes regulate the expression of cytokine and can affect the transcriptional activity ${ }^{[26]}$. A single base pair polymorphism which is located at $-308 \mathrm{G}[\mathrm{A}$ in TNF-a gene is associated with a state of high TNF- $\alpha$ production and susceptibility to several diseases. It is responsible for inter individual differences in TNF-aproduction. ${ }^{[27]}$

In this study, patients with AVF dysfunction are higher heterozygous regarding the gene polymorphism compared to patients with normal functioning AVF and control subjects and no significant difference between patients with functioning AVF \&control group, this mean that genetic polymorphism may paly role in AVF dysfunction.

Sener EF etal. ${ }^{[28]}$ reported that genotype distribution of TNF$\alpha-308 \mathrm{G}>\mathrm{A}$ in patients with AVF thrombosis was significantly different from the patients without thrombosis $(\mathrm{p}=0.008)$ and propose that TNF- $\alpha-308 \mathrm{G}>\mathrm{A}$ genotype may be a potential genetic marker on HD patients with AVF thrombosis.

Buraczynska $\mathrm{M}$ et $\mathrm{al}^{[29]}$, also studiedThe A allele of the TNF -308 polymorphismand found it more frequent in the ESRD group than in control individuals. The odds ratio (OR) for the risk allele was 2.05 .In the subgroup of ESRD patients with CVD, the OR was 5.76. relative to ESRD patients without CVD. They reportedthat the A allele of the TNF 308 polymorphism is associated with CVD in hemodialysis ESRD patients. And if confirmed in prospective studies, it may be a predictor of increased susceptibility to CVD in these patients.

In agreement with the current work, Girndt et al. ${ }^{[30]}$ reported that Inflammation is associated with enhanced development of atherosclerosis, endothelial dysfunction, and vessel wall proliferation. Therefore, genotypes of pro inflammatory cytokines mightinfluence the patency of AVF or AVGs by modifying vessel wall remodeling. A large array of genetic polymorphisms within pro-inflammatory cytokine genes is known, many of them with relevant functional consequences. To date, only the tumor necrosis factor-a (TNF-a) gene has been studied in relation to fistula patency. ${ }^{[31]}$.

Regarding factor $\mathrm{V}$ Leiden gene mutation there was no difference between the group with AVF dysfunction and those with normal AVF as $(\mathrm{p}=0.104)$ while there was significant difference between group with AVF dysfunction \&control group as $(\mathrm{p}=0.002)$.

Verschuren $\mathrm{JJ}$ et al, ${ }^{[32]}$ studied 479 incident hemodialysis patients between January 1997 and April 2004. Follow-up lasted 2 years or until AVF failure, in total, 207 (43.2\%) patients developed AVF failure. After adjustment, two SNPs (single nucleotide polymorphism)were significantly associated with an increased risk of AVF failure. Patients with factor $\mathrm{V}$ Leiden had a hazard ratio of 2.54 (1.41 to 4.56) to develop AVF failure. The other SNPs were not associated with AVF failure.

Emirogullari E.F. et al ${ }^{[33]}$ had studied31 HD patients with AVF thrombosis and $51 \mathrm{HD}$ patients without AVF thrombosis and reported thatthere were no significant differences between HD patients with and without AVF thrombosis in terms of Factor $\mathrm{V}$ Leiden andProthrombin G20210A mutations this result supports ours. 


\section{International Journal of Science and Research (IJSR) \\ ISSN (Online): 2319-7064}

Index Copernicus Value (2013): 6.14 | Impact Factor (2015): 6.391

Also in ourstudy we did not find anysignificant difference between the group with AVF dysfunction and those with normal functioning $\mathrm{AVF}$ as regard factor $\mathrm{V}$ Leiden gene mutation.

Rios et al, ${ }^{[34]}$ stated ,in a cross-sectional study included 195 patients with end stage renal disease (ESRD) on HD for more than six months, that HD patients were allocated into two groups according to the occurrence (cases, $\mathrm{N}=46$ ) or not (controls, $\mathrm{N}=149$ ) of previous vascular access thrombosis. FV Leiden and prothrombin gene mutations were studied.they found that vascular access thrombosismutation and ABO blood group were not associated with vascular access thrombosis, whereas G20210A mutation in the prothrombin gene was significantly higher in patients with vascular access thrombosis and independently associated with this complication $(\mathrm{OR}=12.0 ; \mathrm{CI} 95 \%=1.8-83.5 ; \mathrm{p}=0.012)$.

In the current study, OPG wassignificantly higher in group with AVF dysfunction than those with functioning AVF and control group while there was no significant difference betweenfunctioning AVF and control group. $(p<0.001)$.

Kim HR et al, ${ }^{[35]}$ studiedserum fetuin-A, OPG and Hsp70 concentrationsin $64 \mathrm{HD}$ patients and studied the association of fetuin-A, OPG and Hsp70 with the degree of AVF stenosis using ultrasonography. They found that the degree of AVF stenosis was positively correlated with OPG levels ( $\mathrm{r}=$ $0.411, \mathrm{p}=0.001)$ and $\mathrm{OPG} /$ fetuin-A ratio $(\mathrm{r}=0.375, \mathrm{p}=$ 0.002). The levels of OPG and OPG/fetuin-A ratio were statistically higher in the group of AVF stenosis $\geq 11.5 \%$. ${ }^{[35]}$

Morena $\mathrm{M}$ et al, ${ }^{[36]}$ studied $128 \mathrm{HD}$ patients with internal AVF and followed up for two years by Doppler ultrasonography and serum albumin, prealbumine, Creactive protein, orosomucoid, calcium, phosphorus, parathyroid hormone, bone-type alkaline phosphatase, OPG and receptor activator of nuclear factor $\mathrm{B}$ ligand were measured. The results confirm that vascular access (VA) thrombosis occurs more frequently upon preexisting stenosis, also demonstrate that mineral metabolism disorders, compared to inflammation, may contribute to VA dysfunction leading to thrombosis ${ }^{[36]}$ which agree with our work as we found that serum Ca level was lower while serum phosphorus level, OPG and iPTH were statistically higher in the group with AVF dysfunction compared to those with normal functioning AVF \&control group. This means that mineral metabolism may play a role in the vascular access failure or dysfunction.

\section{Conclusions}

Serum OPG level and serum TNF-alpha- 308G>Apolymorphism play a role in the arteriovenous fistula dysfunctionin HD patientseven may be early predictors of the fistula dysfunction, while factor V Leiden gene mutation needs further investigations.

\section{Recommendations}

We need further investigation by measuring serum level of TNF \& its receptor and its role in AVF dysfunction plus genetic polymorphism also need further research for the role of coagulation system in fistula dysfunction in patients on HD.

\section{References}

[1] Collins AJ, Foley RN, Gilbertson DT, Chen SC. The state of chronic kidney disease, ESRD, and morbidity and mortality in the first year of dialysis.Clin $\mathrm{J}$ Am SocNephrol 2009;4Suppl 1:S5-11.

[2] Oliver MJ, McCann RL, Indridason OS, Butterly DW, Schwab SJ.Comparison of transposed brachiobasilic fistulas to upper arm grafts and brachiocephalic fistulas. Kidney Int 2001; 60:1532-9.

[3] Allon M. Current management of vascular access. CJASN 2007; 2: 786-800.

[4] Lok CE, Allon M, Moist L, Oliver MJ, Shah H, Zimmerman D. Risk equation determining unsuccessful cannulation events and failure to maturation in arteriovenous fistulas (REDUCE FTM I). J Am SocNephrol 2006; 17:3204-12.

[5] Lee T, Barker J, Allon M. Comparison of survival of upper arm arteriovenous fistulas and grafts after failed forearm fistula. J Am SocNephrol 2007; 18:1936-41.

[6] Vachharajani TJ. Diagnosis of arteriovenous fistula dysfunction.Semin Dial 2012; 25: 445-50.

[7] Roy-Chaudhury P, Sukhatme VP, Cheung AK. Hemodialysis vascular access dysfunction: a cellular and molecular viewpoint. J Am SocNephrol 2006; 17:1112- 27.

[8] Roy-Chaudhury P, Kelly BS, Melhem M, Zhang J, Li J, Desai P, et al. Vascular access in hemodialysis: issues, management, and emerging concepts. CardiolClin 2005; 23:249-73.

[9] Yilmaz R, Kirkpantur A, Altun B. The role of inflammatory activity and atherosclerosis on thrombosedarterio-venous fistula for hemodialysis access. Presented at: $44^{\text {th }}$ Congress of European Renal Association European Dialysis and Transplantation Association, (FP417), June 21-24; Barcelona, Spain; 2007.

[10] Ha jeer AH, Hutchinson IV. TNF-alpha gene polymorphism: clinical and biological implication. Microsc Res Tech 2000; 50: 216-28.

[11] Takayanagi H, Ogasawara K, Hida S, Chiba T, Murata $\mathrm{S}$, Sato $\mathrm{K}$, et al. T-cell-mediated regulation of osteoclastogenesis by signalling cross-talk between rankl and ifn- $\gamma$. Nature 2000; 408: 600-5.

[12] Kiechl S, Schett G, Wenning G, Redlich K, Oberhollenzer M, Mayr A, et al. Osteoprotegerin is a risk factor for progressive atherosclerosis and cardiovascular disease. Circulation 2004; 109: 2175-80.

[13] Sandberg WJ, Yndestad A, Oie E, Smith C, Ueland T, Ovchinnikova O, et al. Enhanced t-cell expression of rank ligand in acute coronary syndrome: possible role in plaque destabilization. ArteriosclerThrombVascBiol 2006; 26: 857-63.

[14] Omland T, Ueland T, Jansson AM, Persson A, Karlsson $\mathrm{T}$, Smith C, et al. Circulating osteoprotegerin levels and 


\section{International Journal of Science and Research (IJSR) \\ ISSN (Online): 2319-7064}

Index Copernicus Value (2013): 6.14 | Impact Factor (2015): 6.391

long-term prognosis in patients with acute coronary syndromes. J Am CollCardiol 2008; 51: 627-33.

[15] Golledge J, McCann M, Mangan S, Lam A, Karan M. Osteoprotegerin and osteopontin are expressed at high concentrations within symptomatic carotid atherosclerosis. Stroke 2004; 35: 1636-41.

[16] Akman B, Afsar B, Ataç FB, Ibis A, Arat Z, Sezer S, et al.Predictors of vascular access thrombosis among patients on the cadaveric renaltransplantation waiting list. Transplant Proc 2006;38(2):413-5.

[17] Arsov T, Miladinova D, Spiroski M. Factor V Leiden is associated with higher risk of deep venous thrombosis of large blood vessels. Croat Med J 2006; 47:433-9.

[18] Moran CS, McCann M, Karan M, Norman P, Ketheesan $\mathrm{N}$, Golledge J. Association of osteoprotogeren with human abdominal aortic aneurysm progression. Circulation 2005; 14: 3119-25.

[19] Seriolo B, Paolino S, Sulli A. Effect of anti-TNF-Alpha treatment on lipid profile in patients with active Rheumatoid arthritis. Ann NY AcadSci 2006; 1069: 414-9.

[20] Williamson MA, Snyder LM, Wallach JB. Wallach's interpretation of diagnostic tests. $9^{\text {th }}$ ed. Philadelphia: Lippincott Williams \& Wilkins Health; 2011.

[21] Kotz S, Balakrishnan N, Read CB, Vidakovic B. Encyclopedia of statistical sciences. 2nd ed. Hoboken, New Jersy: Wiley-Interscience; 2012.

[22] Kirkpatrick LA, Feeney BC. A simple guide to IBM SPSS statistics for version 20.0. Student ed. Belmont, Calif.: Wadsworth, Cengage Learning; 2013.

[23] Sezer S, Ozdemir FN, Arat Z, Turan M, Haberal M. Triad of malnutrition, inflammation, and atherosclerosis in hemodialysis patients. Nephron 2002;91:456- 62.

[24] Kokubo T, Ishikawa N, Uchida H, Chasnoff SE, Xie X, Mathew S, et al. CKD accelerates development of neointimal hyperplasia in arteriovenous fistulas. J Am SocNephrol 2009; 20:1236-45.

[25]Zadeh M, Mohammadipour S, Omrani Z. Correlation between CRP and early failure of arteriovenous fistula (AVF). Med J Islam Repub Iran 2015; 29:219.

[26] Jabe r BL, Rao M, Guo D, Balakrishnan VS, Perianayagam MC, Freeman RB, et al. Cytokine gene promoter polymorphisms and mortality in acute renal failure. Cytokine 2004; 25(5):212-9.
[27] Stenvinkel P, Pecoits-Filho R, Lindholm B. Gene polymorphism association studies in dialysis: the nutrition-inflammation axis.Semin Dial 2005; 18(4):322-30.

[28] Sener EF, Taheri S, Korkmaz K, Zararsiz G, Serhatlioglu F, Unal A, et al. Association of TNF- $\alpha$ $308 \mathrm{G}>\mathrm{A}$ and ACE I/D gene polymorphisms in hemodialysis patients with arteriovenous fistula thrombosis.IntUrolNephrol 2014; 46(7):1419-25.

[29] Buraczynska M, Mierzicki P, Buraczynska K, Dragan M, Ksiazek A. Tumor necrosis factor-alpha gene polymorphism correlates with cardiovascular disease in patients with end-stage renal disease. MolDiagnTher 2007;11(4):257-63.

[30] Girndt M, Heine GH, Ulrich C, Köhler H. Gene polymorphism association studies in dialysis: vascular access. Semin Dial 2007; 20(1):63-7.

[31] Ram S, Bass K, Abreo K, Baier RJ, Kruger TE. Tumor necrosis factor-alpha -308 gene polymorphism is associated with synthetic hemodialysis graft failure. J Investig Med 2003; 51:19-26.

[32] Verschuren JJ, Ocak G, Dekker FW, Rabelink TJ, Jukema JW, Rotmans JI.Candidate gene analysis of arteriovenous fistula failure in hemodialysis patients.Clin J Am SocNephrol 2013; 8(8):1358-66.

[33] Emirogullar EF, Saatci C, Unal A, Sahin A, Ozkul1Y. Prothrombin, Factor-V Leiden, and Plasminogen Activator Inhibitor Type 1 Gene Polymorphisms in Hemodialysis Patients with/without Arteriovenous Fistula Thrombosis. nephrourology monthly 2010; 2(2):314-9.

[34] Rios DR, Fernandes AP, Carvalho MG, Figueiredo RC, Guimarães DA, Reis DR, et al. Hemodialysis vascular access thrombosis: The role of factor $\mathrm{V}$ Leiden, prothrombin gene mutation and $\mathrm{ABO}$ blood groups. ClinChimActa 2011; 412(5-6):425-9.

[35] Kim HR, Kim HK, Oh DJ. Serum osteoprotegerin level is associated with degree of arteriovenous fistula stenosis in patients with hemodialysis. ClinNephrol 2013; 80(5):322-7.

[36] Morena M, Bosc JY, Jaussent I, Dupuy AM, Terrier N, Leray-Moragues $\mathrm{H}$, et al. The role of mineral metabolism and inflammation on dialysis vascular access failure.J Vasc Access 2006;7(2):77-82. 


\section{International Journal of Science and Research (IJSR) \\ ISSN (Online): 2319-7064}

Index Copernicus Value (2013): 6.14 | Impact Factor (2015): 6.391

\section{Tables}

Table 1: Biochemical results of studied groups

\begin{tabular}{|c|c|c|c|c|}
\hline & \multicolumn{2}{|c|}{ Dysfunction } & \multirow{2}{*}{$\begin{array}{l}\text { Control } \\
(\mathrm{n}=20)\end{array}$} & \multirow[b]{2}{*}{$\mathrm{P}$} \\
\hline & $\begin{array}{c}\text { No } \\
(\mathrm{n}=20)\end{array}$ & $\begin{array}{c}\text { Yes } \\
(\mathrm{n}=40)\end{array}$ & & \\
\hline Age (years) & $45.0 \pm 11.91$ & $55.55 \pm 10.57$ & $49.45 \pm 4.90$ & $0.001^{*}$ \\
\hline Sig. bet. grps & \multicolumn{3}{|c|}{$\mathrm{p}_{1}<0.001^{*}, \mathrm{p}_{2}=0.158, \mathrm{p}_{3}=0.027^{*}$} & \\
\hline Serum creatinine & $11.52 \pm 3.03$ & $10.93 \pm 2.45$ & - & 0.420 \\
\hline BUN & $26.50 \pm 9.53$ & $26.13 \pm 9.85$ & - & 0.808 \\
\hline HB & $9.82 \pm 0.71$ & $9.49 \pm 0.76$ & $13.08 \pm 0.85$ & $<0.001^{*}$ \\
\hline Sig. bet. grps & \multicolumn{3}{|c|}{$\mathrm{p}_{1}=0.123, \mathrm{p}_{2}<0.001^{*}, \mathrm{p}_{3}<0.001^{*}$} & \\
\hline $\mathrm{Ca}$ & $9.12 \pm 1.18$ & $8.08 \pm 1.08$ & $10.20 \pm 0.34$ & $<0.001^{*}$ \\
\hline Sig. bet. grps & \multicolumn{3}{|c|}{$\mathrm{p}_{1}<0.001^{*}, \mathrm{p}_{2}=0.001^{*}, \mathrm{p}_{3}<0.001^{*}$} & \\
\hline $\mathrm{Ph}$ & $5.96 \pm 1.75$ & $7.57 \pm 1.95$ & $3.18 \pm 0.48$ & $<0.001^{*}$ \\
\hline Sig. bet. grps & \multicolumn{3}{|c|}{$\mathrm{p}_{1}<0.001^{*}, \mathrm{p}_{2}=0.001^{*}, \mathrm{p}_{3}<0.001^{*}$} & \\
\hline iPTH & $235.59 \pm 224.54$ & $416.53 \pm 446.17$ & $46.35 \pm 11.13$ & $<0.001^{*}$ \\
\hline Sig. bet. grps & \multicolumn{3}{|c|}{$\mathrm{p}_{1}=0.038^{*}, \mathrm{p}_{2}<0.001^{*}, \mathrm{p}_{3}<0.001^{*}$} & \\
\hline $\mathrm{HsCRP}$ & $6.22 \pm 10.0$ & $8.60 \pm 5.23$ & - & $<0.001^{*}$ \\
\hline \multicolumn{5}{|l|}{ Lipid profile } \\
\hline Cholesterol & $172.15 \pm 44.93$ & $205.48 \pm 43.90$ & $130.80 \pm 27.43$ & $<0.001^{*}$ \\
\hline Sig. bet. grps & \multicolumn{3}{|c|}{$\mathrm{p}_{1}=0.004^{*}, \mathrm{p}_{2}=0.002^{*}, \mathrm{p}_{3}<0.001^{*}$} & \\
\hline TG & $128.15 \pm 53.19$ & $190.93 \pm 115.1$ & $92.92 \pm 8.35$ & $<0.001^{*}$ \\
\hline Sig. bet. grps & \multicolumn{3}{|c|}{$\mathrm{p}_{1}=0.030^{*}, \mathrm{p}_{2}=0.072, \mathrm{p}_{3}<0.001^{*}$} & \\
\hline LDL & $118.45 \pm 34.73$ & $125.90 \pm 44.64$ & $77.05 \pm 8.49$ & $<0.001^{*}$ \\
\hline Sig. bet. grps & \multicolumn{3}{|c|}{$\mathrm{p}_{1}=0.643, \mathrm{p}_{2}<0.001^{*}, \mathrm{p}_{3}<0.001^{*}$} & \\
\hline HDL & $41.60 \pm 2.98$ & $37.98 \pm 4.20$ & $48.38 \pm 3.81$ & $<0.001^{*}$ \\
\hline Sig. bet. grps & \multicolumn{3}{|c|}{$\mathrm{p}_{1}=0.001^{*}, \mathrm{p}_{2}<0.001^{*}, \mathrm{p}_{3}<0.001^{*}$} & \\
\hline
\end{tabular}

Table 2: Comparison between groups regarding TNF- $\alpha$ gene, factor V mutation and OPG

$$
\chi^{2}: \text { Chi square test }
$$

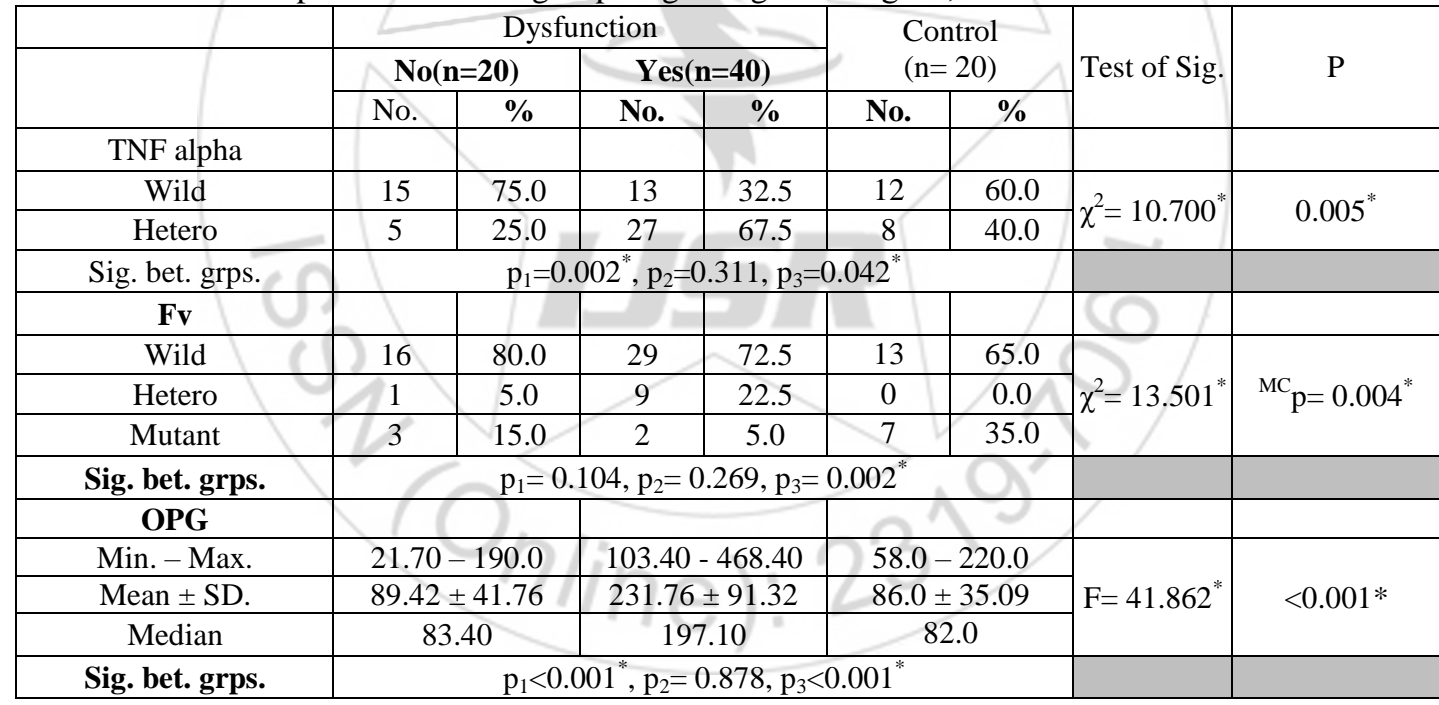

MC: Monte Carlo for Chi square test

F: F test (ANOVA), Sig. bet. grps was done using Post Hoc Test (LSD)

$\mathrm{p}_{1}$ : $\mathrm{p}$ value for comparing between No and yes

$\mathrm{p}_{2}: \mathrm{p}$ value for comparing between No and control

$\mathrm{p}_{3}: \mathrm{p}$ value for comparing between yes and control

*: Statistically significant at $\mathrm{p} \leq 0.05$ 
International Journal of Science and Research (IJSR)

ISSN (Online): 2319-7064

Index Copernicus Value (2013): 6.14 | Impact Factor (2015): 6.391

Table 3: Relation between dysfunction with TNF alpha gene, factor V mutation and OPG

\begin{tabular}{|c|c|c|c|c|c|c|}
\hline & \multicolumn{4}{|c|}{ Dysfunction } & \multirow{3}{*}{ Test of Sig. } & \multirow{3}{*}{$\mathbf{P}$} \\
\hline & \multicolumn{2}{|c|}{$\operatorname{No}(n=20)$} & \multicolumn{2}{|c|}{ Yes $(n=40)$} & & \\
\hline & No. & $\%$ & No. & $\%$ & & \\
\hline \multicolumn{7}{|l|}{ TNF alpha } \\
\hline Wild & 15 & 75.0 & 13 & 32.5 & \multirow{2}{*}{$\chi^{2}=9.676^{*}$} & \multirow{2}{*}{$0.002^{*}$} \\
\hline Hetero & 5 & 25.0 & 27 & 67.5 & & \\
\hline \multicolumn{7}{|l|}{ Fv } \\
\hline Wild & 16 & 80.0 & 29 & 72.5 & \multirow{3}{*}{$\chi^{2}=4.051$} & \multirow{3}{*}{${ }^{\mathrm{MC}} \mathrm{p}=0.105$} \\
\hline Hetero & 1 & 5.0 & 9 & 22.5 & & \\
\hline Mutant & 3 & 15.0 & 2 & 5.0 & & \\
\hline OPG & & & & & $\mathrm{T}$ & $\mathrm{P}$ \\
\hline Min. - Max. & \multicolumn{2}{|c|}{$21.70-190.0$} & \multicolumn{2}{|c|}{$103.40-468.40$} & \multirow{3}{*}{$8.277^{*}$} & \multirow{3}{*}{$<0.001 *$} \\
\hline Mean \pm SD. & \multicolumn{2}{|c|}{$89.42 \pm 41.76$} & \multicolumn{2}{|c|}{$231.76 \pm 91.32$} & & \\
\hline Median & \multicolumn{2}{|c|}{83.40} & \multicolumn{2}{|c|}{197.10} & & \\
\hline
\end{tabular}

$\chi^{2}, \mathrm{p}: \chi^{2}$ and $\mathrm{p}$ values for Chi square test for comparing between the two groups

*: Statistically significant at $\mathrm{p} \leq 0.05, \mathrm{MC}$ : Monte Carlo for Chi square test, t: Student t-test 